\title{
波板スレートの経年劣化に関する研究 \\ CORRUGATED ASBESTOS CEMENT SHEET : DETERIORATION WITH YEARS IN SERVICE
}

\author{
長谷川 哲也*, 稲吉 強**, 畑 中 重 光***, 谷川恭雄**** \\ Tetsuya HASEGAWA, Tsuyoshi INA YOSHI, Shigemitsu HATANAKA \\ and Yasuo TANIGAWA
}

\begin{abstract}
Deterioration with years in service of corrugated asbestos cement sheet (slate) is investigated experimentally. This material is widely used for roofing of factories. The present paper provides the properties of the slate being used for up to 35 years.

Following experimental items are discussed, based on the experimental data.

1. Appearance changes: thickness, cross sectional density, interlayer segregation

2. Change in water absorption

3. Change in chemical property: $\mathrm{pH}$, chemical composition

4. Change in mechanical property: flexural strength, Charpy impact value

From the obtained experimental data, it is assumed that the flexural strength of the slate almost constantly decreases with years in service. Such tendency coincides with the fact reported by users, while that can not be predicted from the experimental data reported earlier.
\end{abstract}

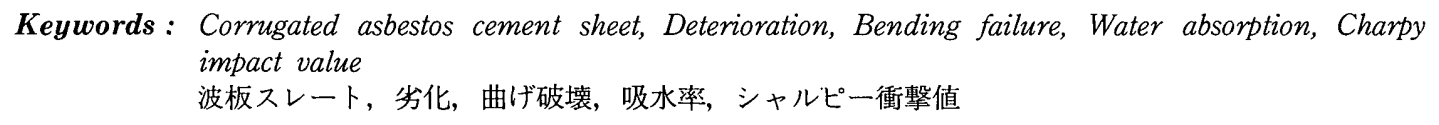

1.はじめに

波板スレートは，一般にセメントと石綿を混合したスレートを波 形に成形したもので, 主として建物の屋根葷き材や外装材として使 用されており，波形スレートとも呼ばれている。波板スレートがわ が国で数多く使用されるようになったのは昭和 30 年頃である。最初 は小波スレートのみの生産であったが, 後に大波スレートの生産も 開始された。以来, 波が梁く, 強度の高い大波スレートは主に屋根 材として，小波スレートは壁材として使われてきた ${ }^{3), 4}$ 。

波板スレート屋根の場合, ある程度以上年数を経ると, 割れや漏 水などの不具合が発生し, その不具合箇所の補修を行う職人が, 経 年によって弱くなった屋根を踏み拔いて落下事故を引き起こす場合 もある。このように，現場サイドでは常識化された波板スレートの 経年にともなう劣化の進行について, 過去の調查研究では明確な説 明がなされておらず，波板スレートの耐用年数も定かではない。

補修や取替之時期に何の目安も無いため, 現状では建物（工場が 多い）所有者によって，メンテナンスの時期および方法は全く違っ ている。すなわち屋根の葺替之工事は, 安全上の問題から当該工場 の操業停止を伴うなど, 一般的に工場の生産活動の調整を含んだ難 工事となっており, 補修時期, 補修方法および葺替之時期の明確化
が望まれている。現実には，ある所有者は必要性に疑問を感じなが ら定期的に草替えを行っているのに对し, 別のある所有者は, 常に 不安を抱きながら，30年近くも堇替えを行っていないという状況で ある。

筆者らは, 最近, 愛知県内の大手自動車製造会社の所有する工場 群に使用されている波板スレートの少化状況を調查する機会を得 た。本報では, 補修時期, 補修方法および莫替え時期を判断するた めの基礎資料として，この会社工場において，4 35年の間使用さ れている波板（大波）スレートの不具合状況の調査結果を報告する とともに，スレートの経年による少化現象について物理的および化 学的側面から検討する。

\section{2. 大波スレートの不具合の実例}

前述の会社では, 約35年前から最近まで, 各所で工場建設を行っ てきた。それらの工場の屋根材については漏水等に対するメンテナ ンスが継続して行われている。図1に1994年の集中豪雨後に行った 全工場の屋根波板スレート（大波）の割れや漏水に対する点検結果 (不具合率)を示す。なお, 図中の縦軸の不具合率は以下のように定

\footnotetext{
本稿は，文献1)およU゙2)に加筆・修正を行ったものである。

*日本診断設計( (侏)

** トヨタ自動車・建築デザイン室 室長

*** 三重大学工学部建築学科 教授. 工博

**** 名古屋大学工学部建築学科 教授. 工博
}

Japan Architectural Examination and Design Office Co. Ltd.

General Manager, Dept. of Architecture \& Engineering, Toyota Mortor Corporation

Prof., Dept. of Architecture, Faculty of Engineering, Mie Univ., Dr. Eng. Prof., Dept. of Architecture, Faculty of Engineering, Nagoya Univ., Dr. Eng. 
義した。ここで不具合とは，漏水および割れを示す。

不具合率 $(\%)=\frac{\text { 不具合を生じたスレート枚数 }}{\text { 調査した全スレート枚数 }} \times 100$

このデータには若年の物件が少なく，既に補修が行われた物件も 対象としているので，経過年数と不具合率の間に明確な相関は見ら れない。ただし，20年以上経過した工場ではかなりの割合で不具合 が発生していることがわかる。

\section{3．波板スレートに関するJIS 規格と既往の研究}

\section{1 波板スレート (大波) の JIS 規格の变遷}

冒頭に述べた場の屋根材は大波スレートである。大波スレート の力学性能は基本的には JIS 規格（現行の JIS A 5430繊維強化七 メント板）に準じていると考えてよい。このうち曲げ破壊荷重につ いては, 図 2 に示すように, 昭和 23 年から小刻みに改訂が行われ, 約 9 年間で強度が 2 倍に上昇していることに留意する必要がある。 最近では昭和 49 年に曲げ破壊荷重が $350 \mathrm{kgf}$ から $400 \mathrm{kgf}$ 入と約 $14 \%$ 引き上げられている。

\section{2 波板スレートに関する既往の研究}

前島ら スレートの変化を調查した。この報告は，小波スレートについては 施工後 20 年まで, 現在よく屋根材として使われている大波スレート については施工後10年までのデータに基づいている。

\section{1）吸水率}

図 3 によれば，初期の吸水率は $20 \%$ を超えているが施工後 $2 \sim 3$ 年で急速に低下し，5 年以降では約10\%前後まで低下している。

\section{2) 吸水速度}

図 4 によれば，材齢 2 週の製品は水漫後 1 時間で吸水率が約 $20 \%$ まで達するが, 施工後 20 年経過した製品は約 $10 \%$ の吸水率まで達す るのに10時間以上を要している。

\section{3) 曲げ強度}

昭和 20 年 $~ 40$ 年頃の製品の平均強度と JIS 規格値（図 2 ) から判断 して，強度の低下はなく，逆に強度が上昇する傾向が見られた。た だし，曲げ破壊時のたわみは減少した。

4) 遊離石灰量（セメント化学分析委員会法：1954年に準ずる)

生産直後の製品では, 遊離石灰量は $7 \%$ 弱であるが, 初期の段階 で急激に減少する。 2 年経過時点では約 $1 \%$ にまで減少し， 5 年経 過以降はほとんど見られなくなる。

\section{3 検討課題}

以上のように波板スレートに関する既往の研究を調查した結果, その経年劣化についていくつかの検討課題が生じた。以下にその主 なものを列挙する。

1) 文献りに示されているデー夕は小波スレートの場合で施工後 20 年まで，大波スレートの場合では施工後10年までのものである。 すなわち，図 1 において不具合が多く見られた施工後 20 年以上の 大波スレートの経年劣化については不明な点が多い。

2）小波スレートは20年未満であれば，経年にともなって，遮水性 および曲げ強度が向上したと報告されている。つまり経年にとも

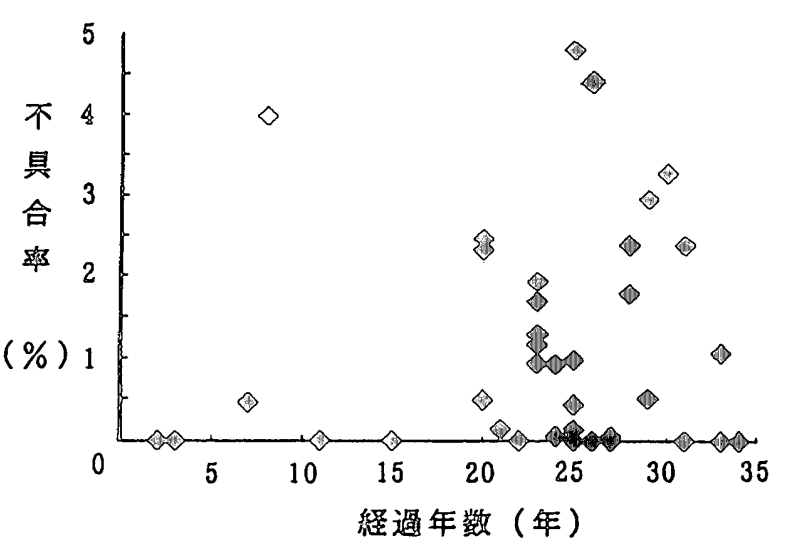

図 1 工場屋根に使用されている大波スレートの不具合率

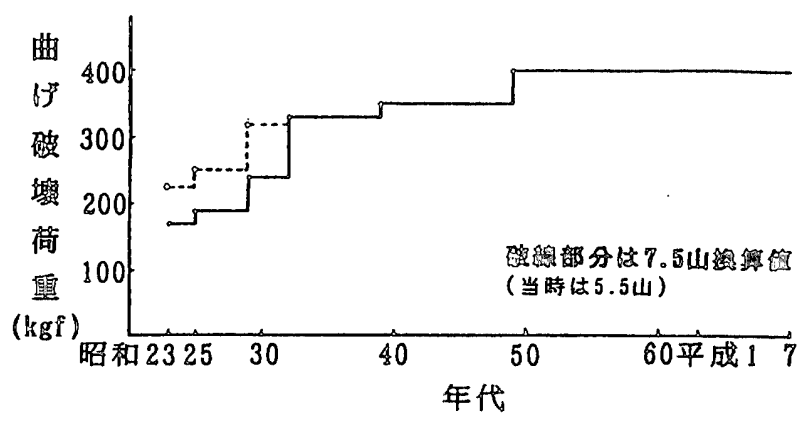

図 2 波板スレート（大波）の曲げ破壊荷重に関するJIS 規格值の変化

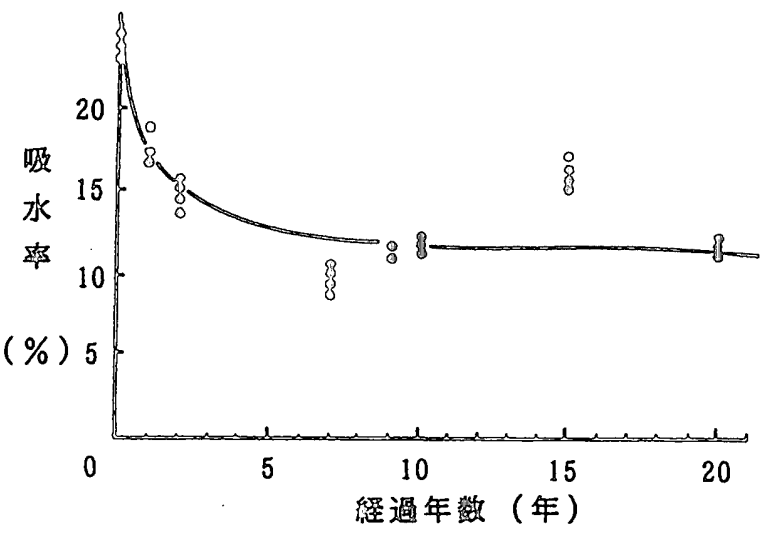

図 3 経年に伴う吸水率の変化 (小波スレート)

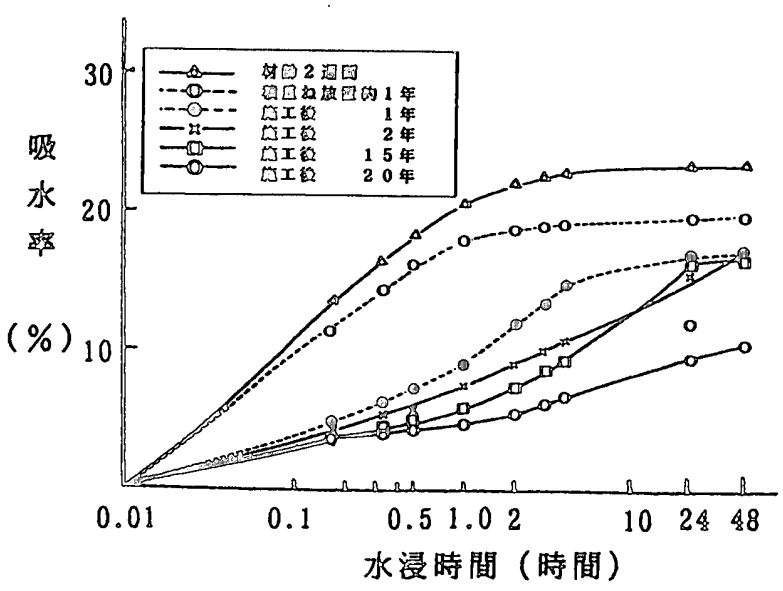

図 4 経年に伴う吸水速度の変化 (小波スレート) ${ }^{5)}$ 
なって外装材としての性能が向上してゆく材料であるとされてい る。しかし, 使用期間35年までの大波スレートの不具合を調べた 図 1 によれば，材質がほぼ等しいからといって，大波スレートに もこの知見をそのまま外捜して考えることができるか疑問であ る。また「屋根材の大波スレートは経年とともに踏み抜きの可能 性が高くなる」といった現場サイドで一般に認識されている事実 とは逆の性能変化である。

3 ) 昭和 49 年に JISの曲げ破壊荷重值が改訂されているが，曲げ強 度と割れ等の不具合との関係は不明である。

\section{4. 経年による板厚等の変化}

\section{1 板厚の変化}

1）出荷時のばらつき

$1,820 \times 950(\mathrm{~mm})$ の波板スレート板の曲げ耐力は，板厚によって 大きく左右される。そのため，年代別の強度を論ずる前に，どのよ うな厚さの製品が出荷されていたのかを調查した。

施工された波板スレートについて，重ね部分で下になった方は減 肉がなく出荷時の厚さを示すものと考えられる（図 5 参照）。した がって，出荷年度別で無作為に抽出した 1 枚の波板スレートについ

て，重ね下部のすべての山頂部と谷底部の厚さ（7点× 2 ）を測定 した。

測定結果を図 6 に示す。ほとんどの年代で谷底部の方が厚くなっ ている。1枚の中でもばらつきはかなり大きく，そのばらつきは古 いものの方がより大きくなる傾向があり，20年経過したものでは最 大值と最小值の差が $2 \mathrm{~mm}$ にも達していた。平均值を見る限りでは 製造年度の新旧による板厚の増加または減少傾向は見られない。

なお，JIS A 5430に準じた测定方法（1枚で 4 箇所）によるデー 夕も収集したが(各経過年数で 3 ３7枚），板厚のばらつきは図 6 と ほぼ同様であった。JISでは「供試体の端（幅方向）から $20 \mathrm{~mm}$ 以上 内側の山頂及び谷底の各 2 点を $1 / 20 \mathrm{~mm}$ 以上の精度を持つ測定器で 計り，4点の平均值を求めて板の厚さとする」と規定されている。 その寸法の許容值は $6.3 \pm 0.6 \mathrm{~mm}$ となっているが，今回の試験結果 もその計り方では許容值以内であった。

\section{2) 経年変化}

前項で述べたように, 板厚の初期值にかなりばらつきがあるため, 経年にともなう板厚の減少を板厚測定だけでは論じることができな い。そのため，1枚の板の中で同じ山頂部の重ね下部と暴露部の厚 さの差をもって減少厚さとした。測定方法はJIS A 5430に準じた。 测定位置は図 7 に示すように山頂部も谷底部も 1 枚につき 2 列ずつ 抽出し, 各列につき重ね下部の板厚と露出部の板厚の差を調べた。 測定結果を図 8 に示す。図によれば，経年にともない板厚の減少が 進行してゆくことがわかる。回帰直線によれば，施工後23年で板厚 は約 $10 \%$ 減少する。また谷底部に比べ山頂部の方が若干減肉が大き いといえる。

\section{2 断面の密度变化}

断面方向の密度変化を顕微鏡写真と密度測定によって評価した。 谷部の断面写真を経過年数別に写真 1 に示す。この写真によれば, 断面の厚さは施工年代によって異なっている。これは経年劣化に

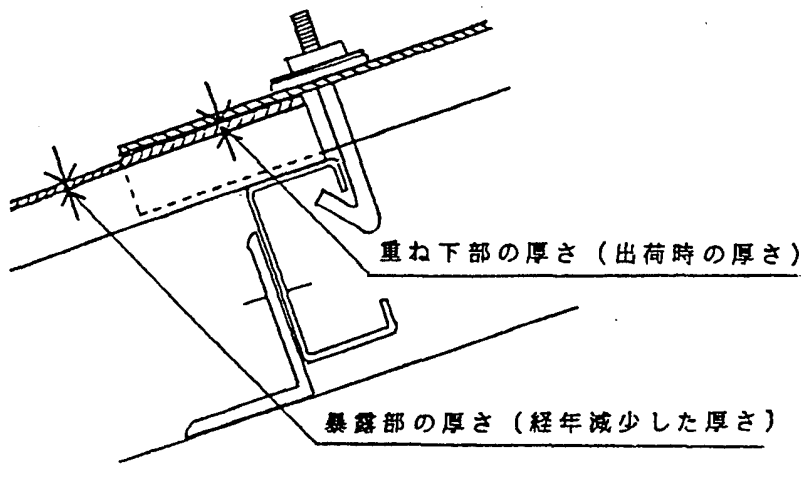

図 5 重ね部位置の断面図

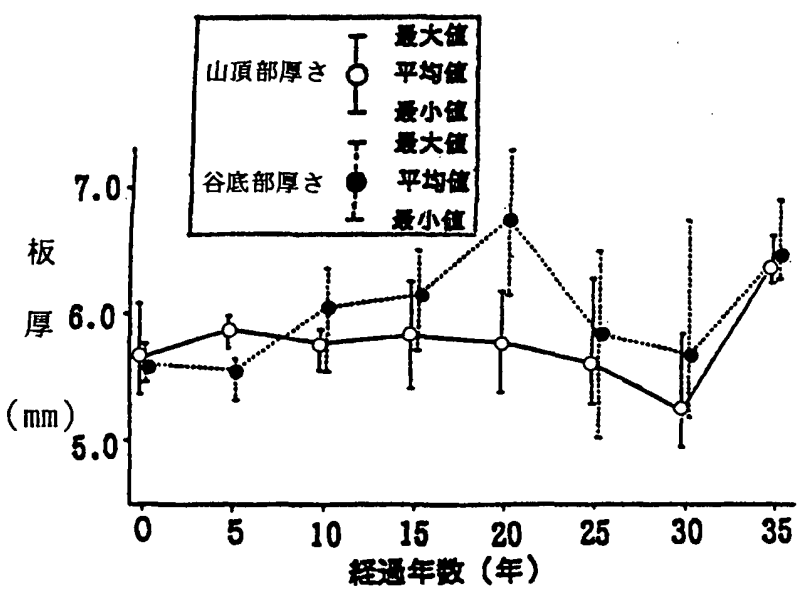

図 6 重ね下部における山頂部と谷底部の板厚変化

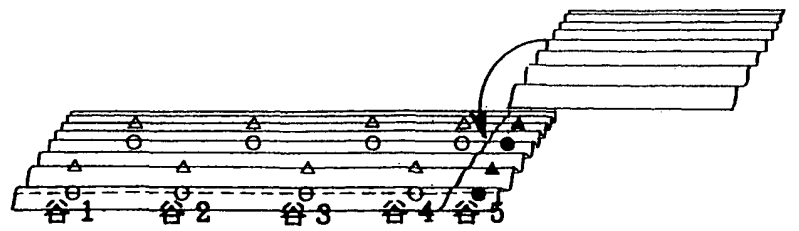

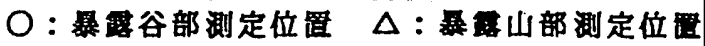

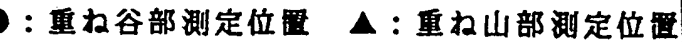

図 7 板厚の測定位置

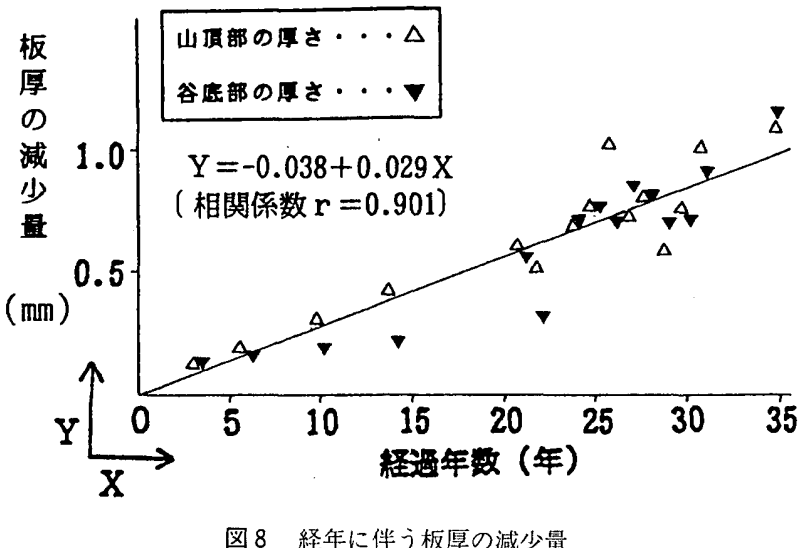




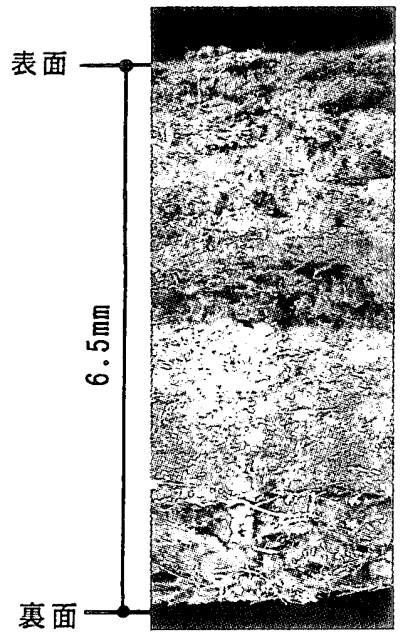

（経過 5年）

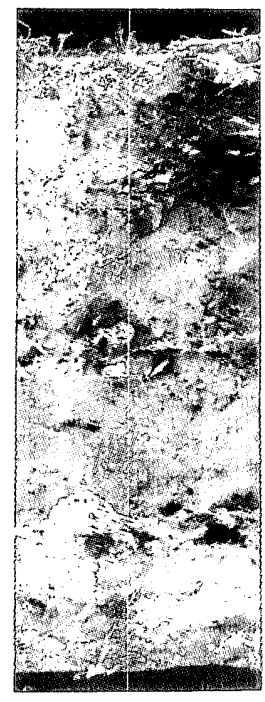

（経過 10年）

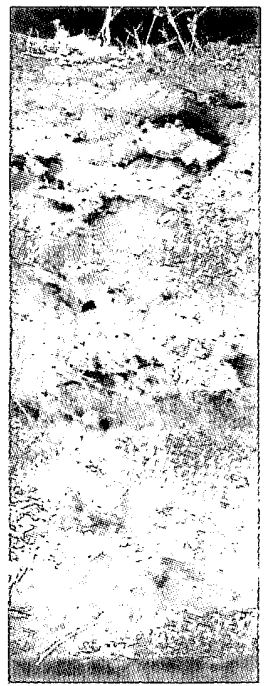

（経過20年）

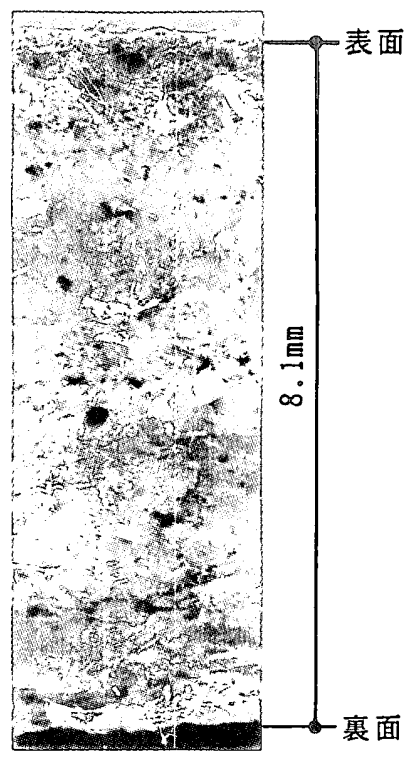

（経過 30年）

写真 1 経過年数別断面写真

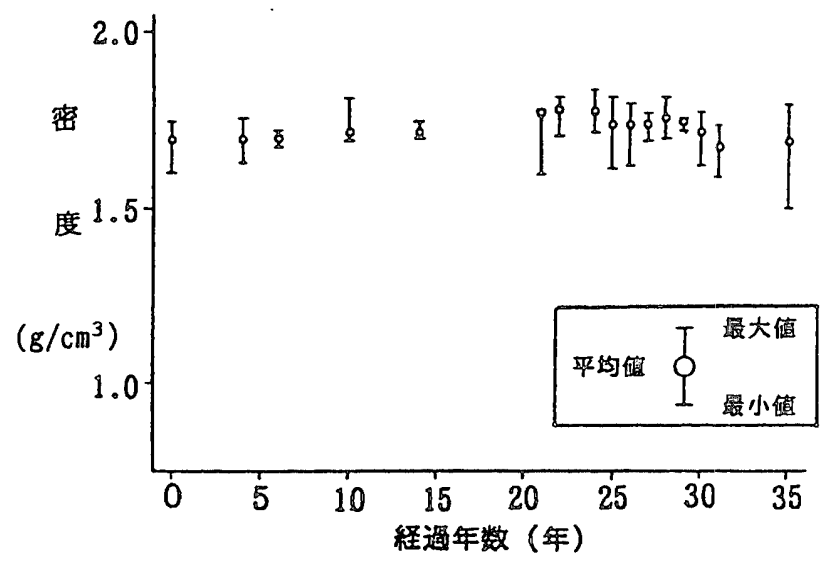

図 9 経年に伴う密度の変化

よって生じた差異ではなく，出荷時の波板スレート自体の厚さが異 なるためである。

経年変化が観察されるのは外部表層のみである。経過 5 年では表 面・内部ともに変化がなく，10年目で表面のセメント硬化体がわず かに消失し，固定されていたアスベストが毛羽立ち始めている。30 年目では，表層から $0.6 \mathrm{~mm}$ 程度がポーラスになっている。一方，内 部および内側（裏面）はこの倍率では見かけ上は何の変化もないよ うに見える。図 9 に，経過年数別の密度測定結果を示す。これによ れば，経年による変化はほとんど見られない。

以上のことから，経年にともなう密度の変化は表層のみで, 内部 においてはほとんど劣化しないものと思われる。

\section{3 層間剝離率の変化}

一般に，波板スレートは所定の厚さまで何枚にも重ねて成型され る。その後, 加圧脱水, 養生, 脱型, 販蔵を経て, 出荷にいたる。 板の重ね部分の界面で剝離が生じている状況を写真 2 に示す。以

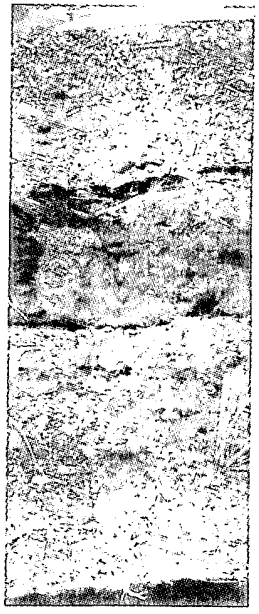

（経過 0年）

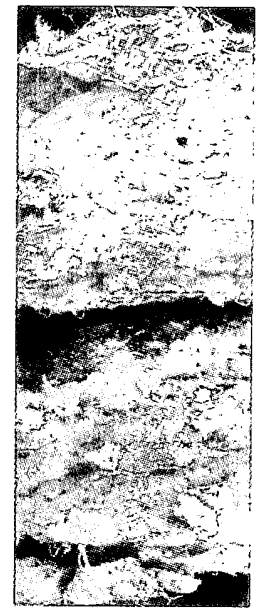

（経過15年）
写真 2 層間剝離状況

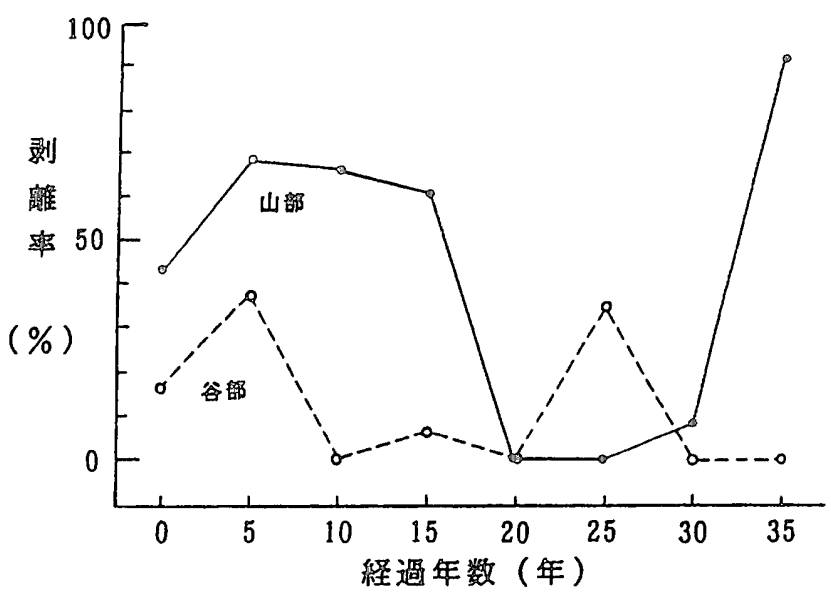

図10 経年に伴う層間剝離率の変化 
下，剝離率について述べる。

調査方法は, 各年代別に無作為に抽出した長さ $850 \mathrm{~mm}$ 以上のサン プルを，山頂と谷底に沿って高速カッターで切断し，その断面を目 視で観察した。板内の位置に関係なく, 剥離の生じている部位の長 さの合計を剝離長さとし，次式によって剥離率を計算した。

$$
\text { 剝離率 }(\%)=\frac{1 \text { 枚中の剥離長さの計 }}{1 \text { 枚中の調査長さの計 }} \times 100
$$

調查結果を図10に示す。山部, 谷部ともに本調查の範囲では経年 による剝離率の增加傾向があるとは言えず，むしろ若年の製品にも 剝離がかなり見られる。また，一般に山部の方が虽離率が高くなる 傾向がある。

\section{5. 経年による吸水特性の変化}

屋根材には高い遮水性能が要求される。経過年数と吸水速度の関 係を調べるために，外部（上側）からの吸水量を経時的に测定した。 ここでは, 同じ経過年数の波板スレートから切り出した暴露部と, 暴露されていない重ね下部を併せて試験した。

1) 試験方法

(1)供試体種別：新品，経過年数の異なる大波スレート

（10年，20年，30年，35年）の暴露部と重ね下部

(2)供試体寸法：20 $\mathrm{mm} \times 50 \mathrm{~mm}$

(3)供試体作成方法：寸法切りした試験片を $100 \sim 110^{\circ} \mathrm{C} て ゙ 2$ 時間乾燥 後, 試験片の側面と裏面をパラフィンでシールして重量を測定し た。

(4)試験方法: 常温の水に浸漬して，所定時間（1，3，9および24 時間後）に引き上げて，表面の付着水を需れウェスで拭き取り，

重量を測定して吸水重量を求めた。

2 ) 試験結果

図11および12に，それぞれ重ね下部および暴露部の吸水速度を示 す。なお吸水率は次式で求めた。

$$
\text { 吸水率 }(\%)=\frac{\text { 吸水重量 }- \text { 初期重量 }}{\text { 初期重量 }} \times 100
$$

重ね下部の吸水速度を示した図11によれば，新品および10年経過 したものでは，およそ 9 時間まで吸水率の増加が著しく，その後の 增加率は小さくなる。一方，施工後30年および35年経過したもので は，新品および10年経過したものに比べて，吸水速度は遅く，24時 間後の吸水染も小さい。

暴露部の吸水速度を示した図12によれば，暴露部では重ね下部と まったく傾向が異なることがわかる。経過年数によって若干数值的 な違いはあるものの，いずれの板も新品と同様に，約 3 時間までは 吸水が激しく，9時間を超えた後はゆっくりと吸水する。すなわち, どの時間でも新品の吸水率に対する割合がほぼ等しい（50 70\%と ほぼ一定)。24時間後の吸水率そのものは約 8 〜 10\%で, 重ね下部に 比べてかなり大きい。

図13に，経過年数と24時間後の単位表面積あたりの吸水率との関 係を示す。図によれば，少なくとも30年までは暴露部も重ね下部も 吸水率は下がり続けている。すなわち，新品の吸水率は $14 \%$ あ゙ある が, 経過年数30年では重る下部の吸水率は $2 \%$ で, 暴露部でも $9 \%$ まで低下している。

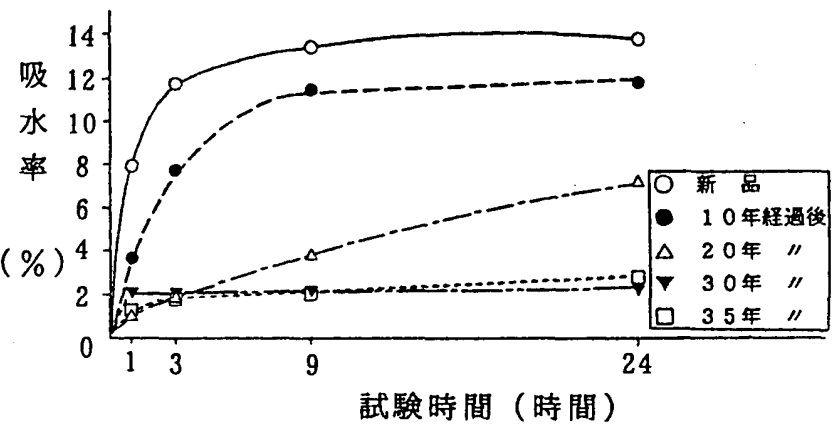

図11重ね下部の吸水速度

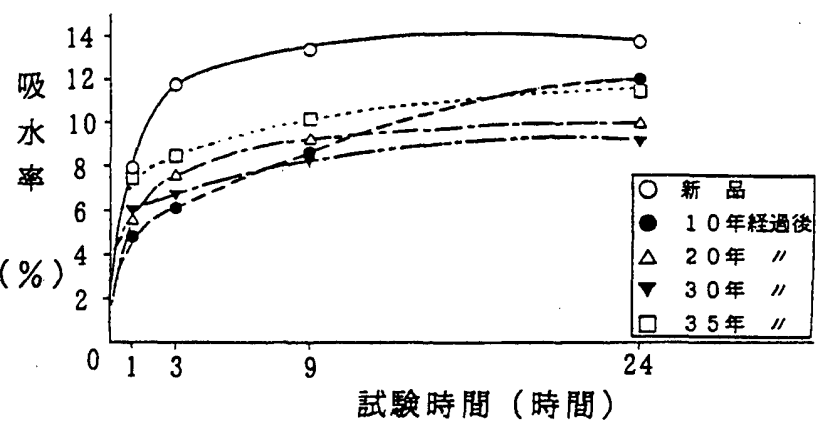

図12 暴露部の吸水速度

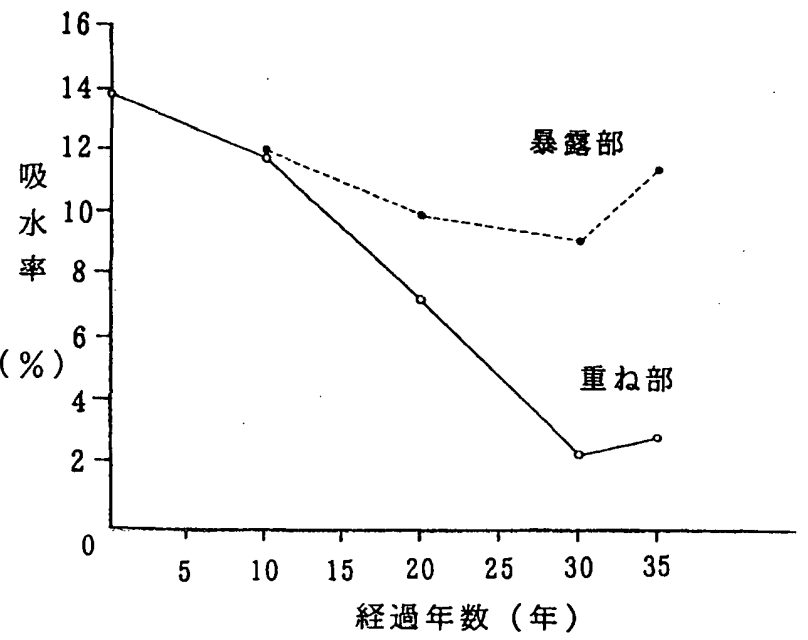

図13 経過年数と吸水率の関係 (24時間後)

表 1 試料の採取位置

\begin{tabular}{|c|c|c|}
\hline 経過年数 & 部位 & \multicolumn{1}{|c|}{ 外部表層からの距離 } \\
\hline 新品 & & $0 \sim 1 \mathrm{~mm}$ \\
\hline 15 年 & 暴露部 & $0 \sim 1 \mathrm{~mm}, 1 \sim 2 \mathrm{~mm}, 2 \sim 3 \mathrm{~mm}$ \\
\hline 35 年 & 暴露部 & $0 \sim 1 \mathrm{~mm}, 1 \sim 2 \mathrm{~mm}, \quad 2 \sim 3 \mathrm{~mm}$ \\
\hline
\end{tabular}

以上の結果のうち，30年ものの重ね下部の 24 時間後の吸水率 $2 \%$ は外装材として極めて良好な值であり，この点だけをとらえれば， 前島らの報告(5にも述べられているように，波板スレートは経年と ともに性能が向上する材料とも言える。この原因については次節で 考察する。 


\section{6. 経年による組成の変化}

吸水率変化の主要因と思われる水酸化カルシウム $\mathrm{Ca}(\mathrm{OH})_{2}$ の炭 酸カルシウム $\mathrm{CaCO}_{3}$ への変化を調べた。

1）試験方法

表 1 に示す部分から削り取った粉末について，X 線回折分析装置 を用いて $\mathrm{Ca}(\mathrm{OH})_{2}$ および $\mathrm{CaCO}_{3}$ の分析を行った。

2) 試験結果

図14に示すように, 新品のものでは外部表層でも $\mathrm{Ca}(\mathrm{OH})_{2}$ が見ら れたが，15年経過したものでは板の外部表層はもとより，板断面の 中央でも $\mathrm{CaCO}_{3}$ Lか見られない。この傾向は施工後35年のものでも 同じであった。したがって，前述した経年にともなう吸水率の低下 は以下のような理由によるものと考えられる。すなわち、スレート 硬化体内の空陌を降雨時に水が充填し，そこへ水酸化カルシウム $\mathrm{Ca}(\mathrm{OH})_{2}$ が溶出し，乾燥時に空気中の $\mathrm{CO}_{2}$ を取り込んで $\mathrm{CaCO}_{3} に$ 変化しつつ空隙を充填したものと考えられる。

ちなみに，施工後35年のものでは $\mathrm{SiO}_{2}$ が見られたが，これは，当 時メーカーによっては增量と強度向上のために珪砂の混入を行って いたことが原因と思われる。なお，この混入は昭和47年頃まで行わ れたが，加工性の点で問題を生じるとの理由から，これ以後は現在 の調合に変更されていることを付記する。

\section{7. 経年による力学特性の变化}

\section{1 曲げ破壊荷重の変化}

工場等の屋根は，建物の中に雨水を浸入させないといった基本的 な性能の他に，各種施設の設置やメンテナンス用通路としての強度 も必要とされる。ここでは一般に強度の指標とされる曲け破壊荷重 の経年による変化を調べた。

\section{1) 試験方法}

試験は図15に示すように, JIS A 5430 5.5曲げ強度試験に準じて 行った。また，ここでは比較的古い波板スレート，すなわち経過年 数21年，30年および35年のものについて供試体数を增やした（表 2 参照)。

\section{2) 試験結果}

試験結果を図16に示す。相関係数は $\mathrm{r}=-0.854$ となり，経年によ る強度の低下傾向が明確に見られた。2.2節で述べたように，経過年 数約20年の波板之レートは，JISの曲げ破壊荷重が $350 \mathrm{kgf}(3430 \mathrm{~N})$ から $400 \mathrm{kgf}(3920 \mathrm{~N})$ に変わった時期に製造された製品でもあり，初 期值が違うことが予想されるため単純な比較はできないが，図16に 見られる強度の低下傾向は明らかに JIS 規格の変化より大きいと言 える。また経過年数 10 年， 21 年，30年および 35 年の板について，曲 げ破壊荷重と板厚の相関関係を表 2 に示す。板厚の測定は，JIS A 54305.3 寸法の測定によった。表 2 の結果より以下のことが考察さ れる。

(1)板厚と曲げ破壊荷重との間には相関があると思われたが，両者の 相関性は極めて弱い。

(2)板厚と曲げ破壊荷重の相関性があまり強くない理由として，厚さ の初期值が異なっている可能性があること, 厚さ以外のファク ターが強度に関係していることなどが考えられる。

(3)波板スレート自体，一般に 1 枚の面の中でも板の厚さがばらつい

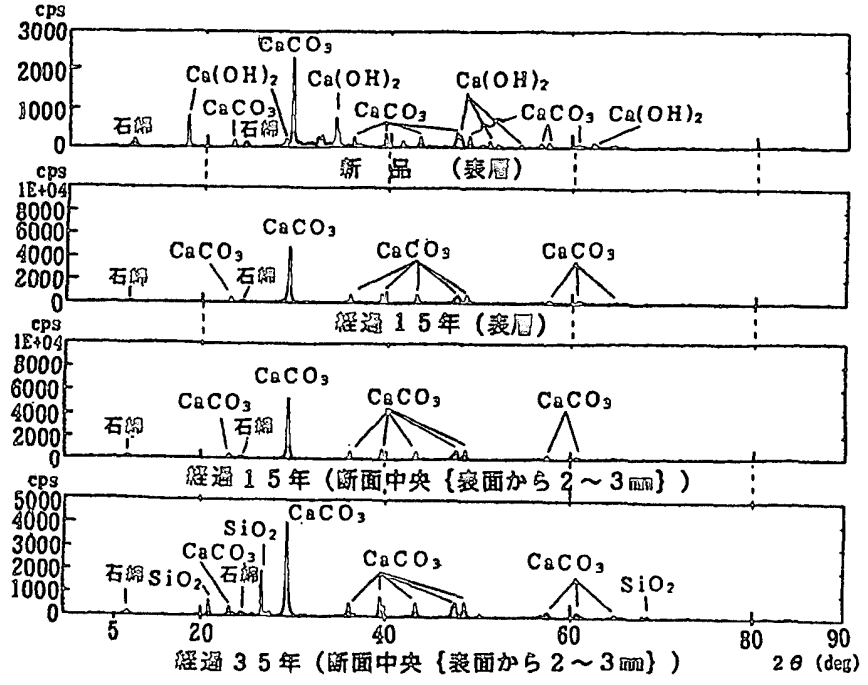

図14 経年に伴j断面の化学成分の変化（粉末 X 線回折による）

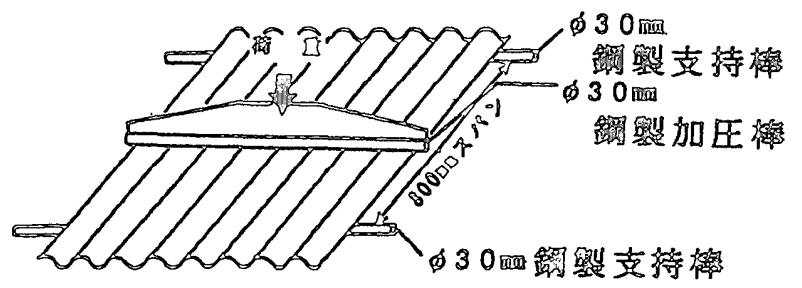

図15 曲げ破壊試験方法

表 2 曲げ破壊荷重と板厚の関係式

\begin{tabular}{|c|c|c|c|}
\hline 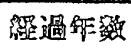 & $\mathrm{n}$ & 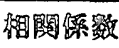 & 回嚅式 \\
\hline 100 & 9 & 0.495 & $Y=619 X+1675$ \\
\hline $2 \| A F$ & 27 & 0.553 & $Y=792 X-703$ \\
\hline 30舐 & 27 & 0.369 & $Y=1070 X-2107$ \\
\hline 35 舒 & 27 & 0.016 & $Y=29 X+3642$ \\
\hline
\end{tabular}

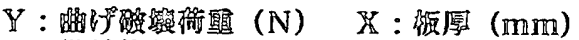

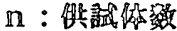

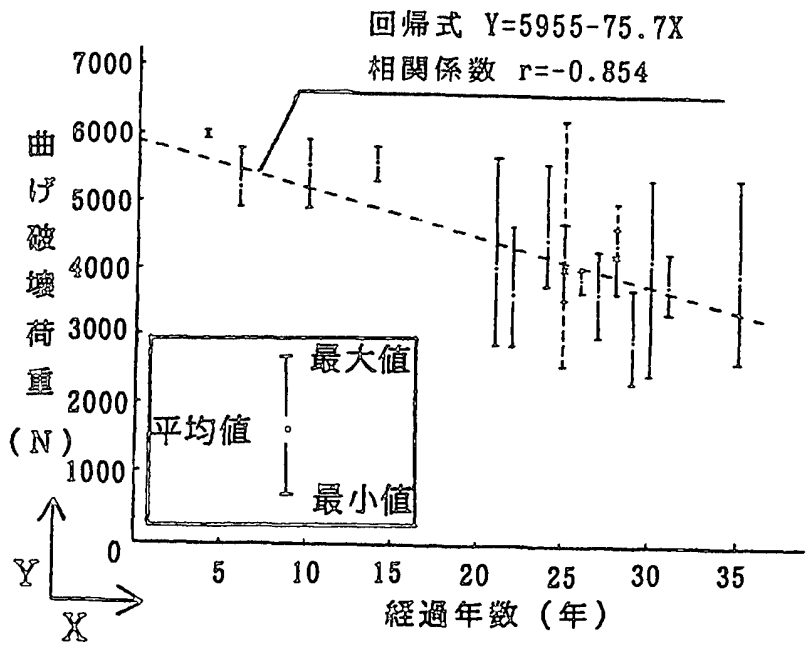

図16 経年に伴う曲け破壊荷重の変化 
ており (図6 参照)，JISによる端部 4 点の測定では，必ずしも応 力の大きい部位の厚さを推定できない可能性がある。

波板スレートの曲げ破壊荷重について以上の知見をまとめれば, 図17のようになる。なお，曲げ破壊時のたわみはいずれも $4 \mathrm{~mm}$ 〜6mm の範囲であり, 経過年数による増大あるいは減少傾向は見ら れなかった。

\section{2 耐衝撃力の変化}

経年にともなう，硬さおよび脆さの変化を調べるためにシャル ピー衝撃試験を行った。

1) 試験方法

供試体は，曲げ破壊試験後の残材から重ね部分と暴露部分につい て， $170 \mathrm{~mm}$ (長さ) $\times 130 \mathrm{~mm}$ ( 1 山を含む幅)を切り取って作製した。 試験方法は，JIS Z 2242に準じた。すなわち，図18に示すような 機械の下部に切り取った供試体を固定し， $3 \mathrm{kgf}(29.4 \mathrm{~N})$ のハンマー 振り子を振り降ろして供試体を破壊する。供試体破壊時の振り子の 振り上げ角度から次式によって供試体の吸収エネルギーを算出し， シャルピー衝撃值とする。

$$
E=M(\cos \beta-\cos \alpha)
$$

ここに, $E$ : シャルピー衝撃值 $(\mathrm{N} \cdot \mathrm{cm})$

$$
\begin{aligned}
& M: \text { ハンマーの回転軸の周りのモーメント }(\mathrm{N} \cdot \mathrm{cm}) \\
& \quad M=W r \\
& W: \text { ハンマーの質量による負荷 }(29.4 \mathrm{~N}) \\
& r: \text { ハンマーの回転軸中心から重心までの距離 }(35 \mathrm{~cm}) \\
& \alpha: \text { ハンマーの持ち上げ角度 }(150 \text { 度 }) \\
& \beta \text { : 供試体破断後のハンマー振り上がり角度 }
\end{aligned}
$$

2 ) 試験結果

試験結果を図19に示す。本試験結果によれば，経年によるシャル ピー衝撃值の増減傾向は見られない（硬さおよび弾力性の変化は明 確には見られない)。また，曲げ破壊荷重の場合，経過年数20年末満 と20年以上の供試体ではかなりの差が見られたが, シャルピー衝撃 試験值では両者の間に明確な差は見られない。

\section{8.まとめ}

本研究では，現在，屋根莫き材として多く使用されている大波ス レートの経年劣化について調查・研究を行った。

対象とした大波スレ一トは材龄35年までのものであり，これまで に報告されている研究結果（材齢10年まで）とは異なる傾向，例之 ば，曲げ破壇荷重が経過年数とともに小さくなる傾向などが明らか となった。本研究によって得られた結果を項目別にまとめると，以 下のようになる。

1) 板厚等の変化について

(1)同一のスレートでも出荷時点で既に厚さのばらつきがかなり大き

く，その差は最大 $2 \mathrm{~mm}$ であった (図 6 参照)。

(2)板厚は経過年数にほぼ比例して減少寸る (図 8 参照)。

(3)経年にともなう密度の変化は表層部のみで，断面内部は経過30年 のものでもほとんど変化していない（写真 1 参照)。

2 ）吸水特性の変化について

(1)吸水率は，暴露部・重ね下部ともに材跲30年まで下がり続ける。
その程度は重ね下部の方が著しく，初期に $14 \%$ 程度あったものが

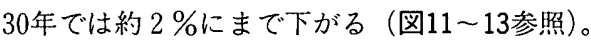

(2)前項で述べた現象は，水和反応時に生成される水酸化カルシウム

\begin{tabular}{|c|c|c|}
\hline $\begin{array}{c}\text { 曲げ破宫荷重に影 } \\
\text { 響を及ぼす要因 }\end{array}$ & $\begin{array}{c}\text { 経年に伴う森化 } \\
\text { または煩向 }\end{array}$ & 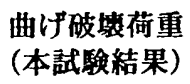 \\
\hline 現在の板厚 & 明確な減少 & \multirow{4}{*}{$\begin{array}{l}\text { 経年に伴う } \\
\text { 低下傾问 } \\
\text { (弱い相関) }\end{array}$} \\
\hline 初期の板厚 & ばらつき大 & \\
\hline 層間剥離 & ばらつき大 & \\
\hline ЛSの板厚測定法 & $\begin{array}{l}\text { 精度に疑問（必 } \\
\text { ずしも破壊断面 } \\
\text { の情報を与える } \\
\text { とは限らない） }\end{array}$ & \\
\hline
\end{tabular}
が炭酸がスと反応して炭酸カルシウムが生成されることにより, コンクリート表面近くから細孔が充媜され，吸水率が低くなった ためと考えられる。

(3)以上より，前島ら5の報告でも述べられているように，波板スレー トは経年とともに遮水性能が向上する材料であると言える。

3 ）力学特性の変化について

図17波板スレートの曲げ破壊荷重に影響を及ば寸諸要因と本試験結果との 関係
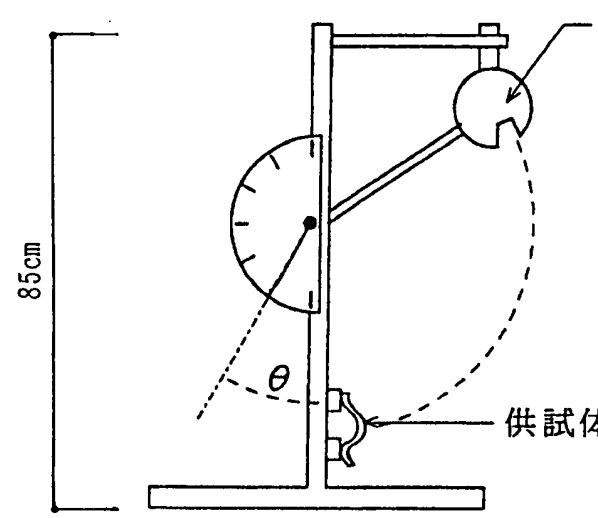

$3 \mathrm{kgf}$ ハンマー $(29.4 \mathrm{~N})$

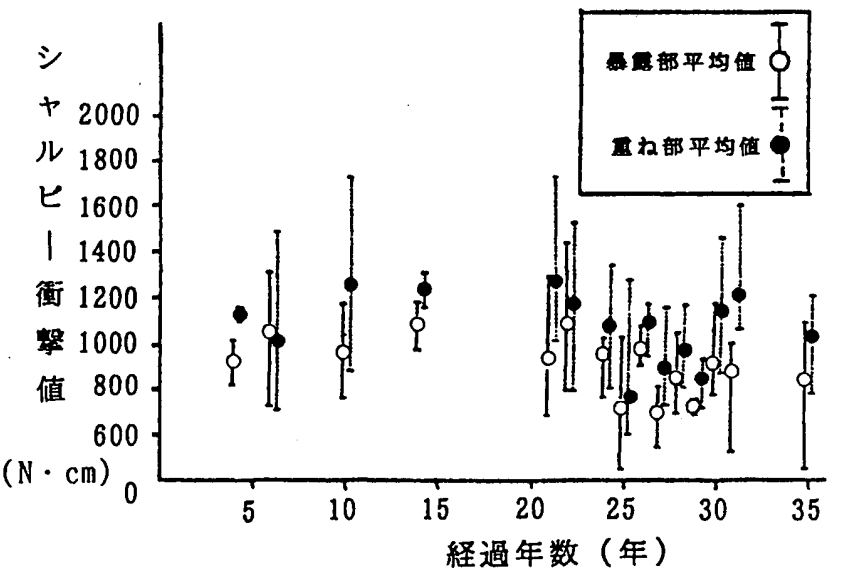

図19暴露部掞よU゙重ね部の経年に伴うシャルピー衝撃値の変化 
(1)曲げ破壊荷重は，全体的にはばらつきが大きいものの，平均值は 経過年数とともに小さくなる傾向が見られる(図16参照)。ばらつ きが大きくなった理由として，当初の厚さにばらつきが大きく経 過年数が多いものが薄いとは限らないこと (図6 参照)，層間剝離 の生じる時期が経過年数とは関係していないこと（図10参照）な どが考えられる(図17参照)。

(2)曲げ破壊時のたわみ量, およびシャルピー衝撃值の試験結果によ れば(図19参照)，経過年数にともなって硬さや弾力性が変化して いるとは言えない。

4) メンテナンスの方針について

(1)波板スレートの遮水性能は経年とともに向上するものの5)，曲げ 強度は経年に伴い低下するため補修・葺替之は必要である。その 時期は，現段階ではおよそ20年(昭和 49 年 JIS 改正以前)が補修の 目安と思われるが，図16の経年に伴う曲げ破䏅荷重の変化を参考 に, 場合に応じて要求性能と安全率を考慮して判断する必要があ る。

(2)曲げ強度の主な少化原因は板厚の減少であると考えられるため補 修にあたっては，これを防ぐ必要がある。

5 ) 今後の課題

前項 4)で述べた補修・弯替之が必要な性能基準を明確にするこ と，およびその簡易診断方法の開発が重要と思われる。また，板厚 の減少をくい止める有効な補修方法の開発も望まれる。

\section{謝辞}

本研究にあたり御指導・御協力を賜った, 浅野スレート侏中央研 究所長 - 岡崎卓也氏, 名古屋支店営業課長 - 对馬更正氏, 名古屋工 場生産課長・久野健二氏および廣川智之氏に深く感謝いたします。

\section{参考文献}

1）長谷川哲也他 3 名：波板スレートの経年劣化に関する研究（その1），日 本建築仕上学会1996年大会学術講演会研究発表論文集, pp.69 72, 1996

2）辰谷川暂也他 3 名：波板スレートの経年少化に関する研究（その2），日 本建筑仕上学会1996年大会学術講演会研究発表論文集, pp.73 76, 1996

3）建築材料実用マニュアル編集委員会：建築材料実用マニュアル, 産業調査 会事典出版センター, p.325, p.327, 1994
4）狩野春一他：波板石綿スレート・石綿セメント板 JIS 解説，石綿スレート 協会技術部会論文集, pp.42 43, 1967

5）前島正一他：長年使用波形スレートの特性,石綿スレート協会技術部会諭 文集, pp.99 108，1967

\section{参考}

スレート（slate）とは，粘板岩や頁岩を薄板状に切り取ったものを称してい たが, 現在では,この天然スレートの他にいくつかの種類の人エスレ一トが製 造されている。致根龩き材としての波板スレートの位置付けを明らかにするた め,参考表に現在用いられている非金属系成形屋根㩰き材の種類を形状別に分 類して示す。

天然スレートの代替品として，石綿を使用した小平板 (約 $400 \mathrm{~mm}$ 角) が大 正 5 年に国産機械によって製造され始めた。その後（第一次世界大戦後），モ ルタル瓦風の厚形スレートおよU゙ $910 \mathrm{~mm} \times 1,820 \mathrm{~mm}$ (または $1,210 \mathrm{~mm} \times$ $2,420 \mathrm{~mm}) の 大$ 型のいわゆる石綿セメント板に発展し, さらにこれに波をつけ た波板スレートへと改良が進んだ4。

参考表 非金属系成形屋根葺き材の種類（文献3に加筆）

\begin{tabular}{|c|c|c|}
\hline 现䖯 & 綡四 & 名林 \\
\hline \multirow{6}{*}{ 平短蚂 } & 自绝石 & 天然スレート \\
\hline & 东口 & ウッドシンタル、ウッドシェイク \\
\hline & 站士 & 部土瓦 (가제) \\
\hline & 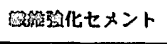 & 生宅用国榅スレート（平板状） \\
\hline & アスフォルト烈 & アスファルトシングル \\
\hline & 符的留 & 不能シンダル \\
\hline 四䤄微损 & 船土 & 能土瓦（姆瓦、スペイン瓦、イタリア瓦） \\
\hline \multirow{2}{*}{ 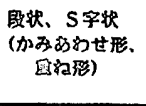 } & 部士 & 秥土瓦（フランス瓦、和形、S顽、洋形) \\
\hline & セタンント梁 & 国形スレート \\
\hline \multirow{5}{*}{ 波饭状 } & \multirow{3}{*}{ 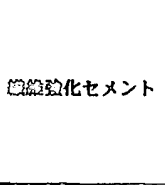 } & 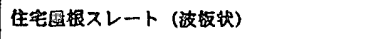 \\
\hline & & 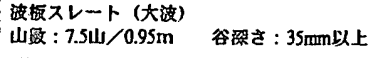 \\
\hline & & 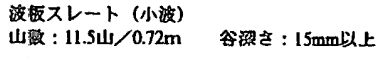 \\
\hline & カラス & 波板ガラス \\
\hline & 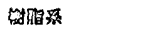 & プラスチック眼淞板 \\
\hline
\end{tabular}

（1997年 3 月10日原稿受理，1997年 7 月16日採用決定） 